\title{
Motorcycling over the Ofenpass: perception of the Swiss National Park and the Ofenpass from the perspective of motorcyclists
}

\author{
Andrea Jauss \& Norman Backhaus
}

Keywords: Swiss National Park, Ofenpass, motorcycling, noise, perception of motorcyclists, traffic management

\section{Abstract}

Visitors to conservation areas rarely expect to hear engine noise while hiking through pristine natural surroundings. Rather, they expect the absence of human induced emissions and therefore react sensitively to unnatural noise. Many visitors of the Swiss National Park - our case study area - are disturbed by noise emissions of motorcycles driving over the Ofenpass, a road that runs right through the park. Some of them are calling for a reduction of this noise or even for a ban of motorcycles on the Ofenpass road. Motorcyclists, however, are also spending money in the region and contribute to the economic livelihood of its inhabitants. The article focuses on motorcyclists and their perception of the park and the noise they are producing. In-depth information about this special practice in the park region was gathered through a triangulation between qualitative interviews, quantitative questionnaires and participant observation. The results show that motorcyclists are a heterogeneous group of tourists, who fulfil their driving passion and lust for travel through their hobby. The majority of them are aware of the noise problem and other emissions they produce and demonstrate an understanding for potential measures to reduce noise. The article concludes with recommendations for mitigating problems related to motorcycling and noise emissions in protected areas.
Profile

Protected Area

Swiss National Park

Mountain range

Alps

Country

Switzerland

\section{Introduction}

Nature protection and recreation are not regarded as going well with exhausts, noise, and congestion caused by motorized transport. Yet most protected areas are accessible by roads and they encourage tourism, which depends on traffic infrastructure. In addition, many national parks - at least in Central Europe are fragmented by roads preceding their implementation. Hence, traffic - and especially noise related to traffic - poses a problem for the management of protected areas. Noise emitted by engines and tyres is audible from afar and can disturb wildlife (cf. Barber et al. 2010; Chan \& Blumstein 2011) and tourists, who expect certain soundscapes in protected areas (Miller 2008). For technical reasons noise emitted by motorcycle engines travels further than noise from cars. Hence, when tourists complain about traffic noise they often attribute this to motorcyclists who consequently are regarded as (noise) polluters. This paper focuses on the practice of motorcycling in protected areas and on the rarely investigated motorcyclists' view of their driving behaviour in and perception of such areas. The paper's aim is to contribute to noise management in protected areas that not only perceives motorcyclists as a source of noise but also takes their point of view and motives into account. As an example we use a case study from the Ofenbergstrasse, a road that cuts through the Biosphere Reserve Val Müstair Parc Naziunal (Jauss 2012).

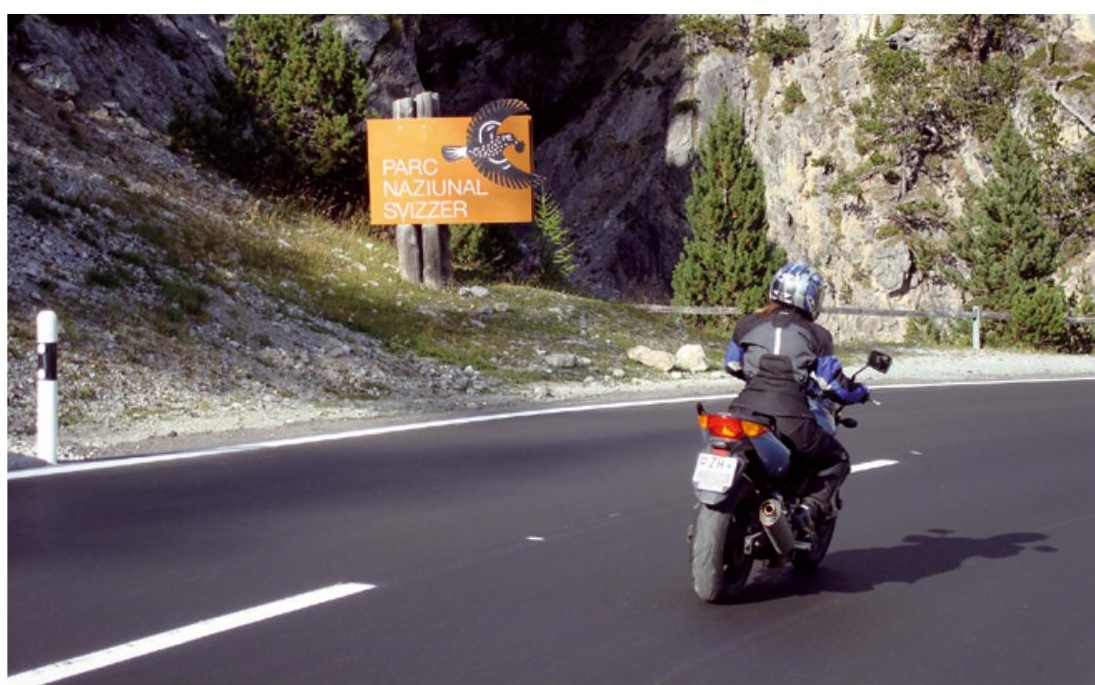

Figure 1 - Welcome to the Swiss National Park - A sign that is often overlooked by motorcyclists. (C) Andrea Jauss

Park visitors and many people who do not engage in the practice of motorcycling often identify those who do as a group of people with a distinct behaviour (related to a lifestyle) that is perceived as unpleasant and annoying. Applying a practice-oriented approach (cf. Schatzki 2002), we regard motorcycling as a doing that is momentary and related to practices of other social actors and to places where these practices are bound, meant, or expected, to happen. Consequently, if the people that were interviewed for this study are described as motorcyclists, we regard them as people 


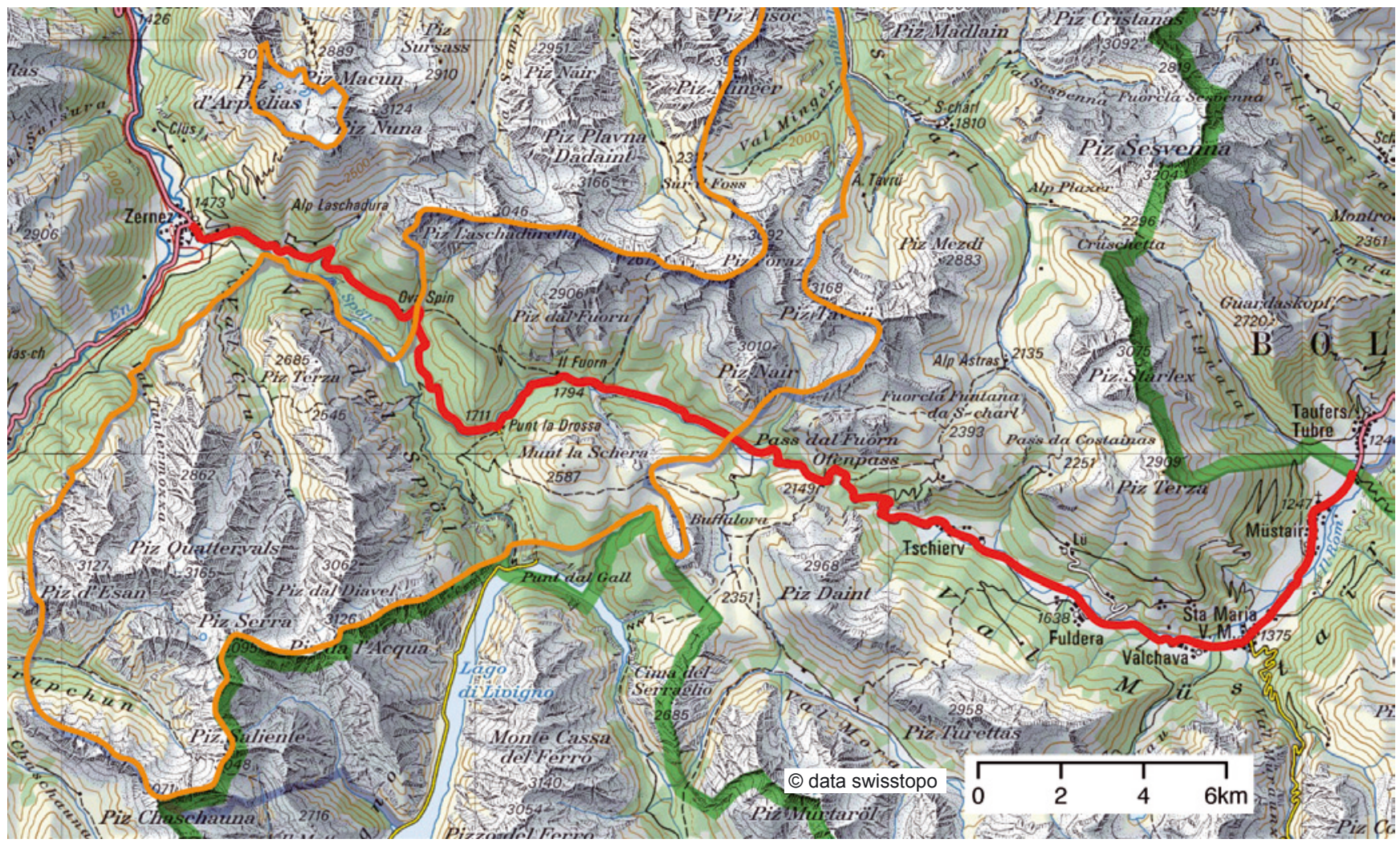

Figure 2 - Location of the Ofenbergstrasse in red. Boundary of the SNP in orange. Map reproduced by permission of swisstopo (BA12095); road and park boundaries, authors' emphasis

practicing motorcycling at a certain time in a certain place. Hence the observed and questioned motorcyclists are - according to a practice-oriented approach only motorcyclists when they are practicing it or talking about it. Their practice is pertaining to distinct social and physical, but also spatial and temporal, contexts, such as a mountain road leading through a conservation area. Consequently, mitigation processes relating to noise emissions should consider altering practices rather than people.

\section{Context}

The Ofenbergstrasse (Ofenpass summit 46 38' 22' $\mathrm{N}, 10^{\circ} 17^{\prime} 32^{\prime \prime} \mathrm{E}$ ) connects the Inn valley with Swiss Val Müstair and Italian Val Venosta and crosses through the Swiss National Park (SNP) and Val Müstair Biosphere Reserve (BVM) (Figure 2). The mountain pass, Ofenpass, is used for access to both SNP and the Val Müstair and as a feeder road for freight transport and tourist traffic to Italy and Austria. Because of these multiple uses, the Ofenpass is a place where interests and expectations of different stakeholders clash. Beside motorcyclists who enjoy the ride on the curvy road, hikers use the Ofenbergstrasse as an entry point to the SNP, bicyclists climb up it to reach the pass and motorists use it as fast and scenic connecting road. At peak times 4200 motorized vehicles per day are counted on the Ofenpass (ASTRA \& BFS 2011). According to the authors' own, not representative, observations, most vehicles are cars (unfortunately no data are avail- able about the ratio between cars and motorcycles). These transit routes over the Swiss Alps are important for the connection between the inner-Alpine economies and provide access to tourist resorts and points of interest. The challenge for the population and political actors of the Alpine valleys concerned is to find a balance between economic gain (Rey 2011) that is also claimed by actors from the tourism industry and adverse emissions that is in line with sustainable development (Birkenfeld 2002; Bätzing 1998).

Both the number of motorcycles and their share of total kilometres driven by private traffic have been increasing in Switzerland and Germany since the 1990s (BFS 2010; Kraftfahrt-Bundesamt Deutschland 2013).

Moreover, motorcycling has changed from a mere means of transport to a status symbol (Kohler 2005, 2007; Znoj 2011). Not just in the SNP, but also in the villages of Val Müstair, the augmented traffic is increasingly perceived as a burden. The SNP's visitor surveys indicate a high level of satisfaction of the park visitors with the park in general (almost 50\% have nothing to complain, even if specifically asked, according to Campell et al. 2007), however, traffic and the associated noise is perceived as a nuisance. Even though only $4 \%$ of the respondents asked by Campell et al. (2007) complained about noise (just behind crowding and people who do not observe the rules, both at $9 \%$ ), the noise produced by motorcycles is perceived as particularly annoying (Meier 2010; Lozza 2009; Omlin \& Brink 2010; Züllig 2007). Even among the local population the dissatisfaction with noise, traffic holdups, 
speeding and accidents is growing. During the summer of 2010, the management of the SNP addressed the noise problem by analysing noise emissions by motorcyclists in comparison with emissions of cars on the Ofenbergstrasse (Heutschi 2010; Omlin \& Brink 2010) and came to the conclusion that the overall noise - measured in decibels $\mathrm{dB}(\mathrm{A})$ - emitted from this road is between 75 and (health-threatening) $105 \mathrm{~dB}(\mathrm{~A})$. This is way above the $65 \mathrm{~dB}(\mathrm{~A})$ limit that is considered appropriate for recreation areas (BAFU 2011).

Noise is more than sound exceeding a certain decibel level. Whether a sound is perceived as annoying noise largely depends on individual expectations of soundscapes, on personal attitudes towards the sources of noise and on the tolerance for specific noises (Mace et al. 2004; Miller 2008). One expects a city centre to sound different from a protected area, yet not necessarily louder. A tropical rainforest can be ear-piercingly loud and SNP's Val Trupchun during rutting season is quite noisy. However, the quality attributed to noises emitted by crickets or deer vs. cars or motorcycles is perceived differently. Traffic noise is increasingly regarded as disturbing by tourists and local people living near major roads (Lozza 2009). In the national park region, noise emitted by motorcycles is seen as particularly disturbing (Campell et al. 2007; Züllig 2007; Lozza 2009; Meier 2010; Omlin \& Brink 2010). The reasons for an increased perturbation potential of motorcycles lie in technical aspects (i. e. the difficulty with insulating low frequency emitters, higher engine speed, and quicker engine response) and with the preferences of the drivers. Low frequencies travel farther in narrow valleys and gorges and moreover are perceived as louder, even at the same decibel level (Heutschi 2010). Hence people's observations that motorcycles are louder mostly depend on human perception but also on the fact that some motorcyclists exceed $100 \mathrm{~km} / \mathrm{h}$, above which a motorcycle engine is louder than a car engine (Heutschi 2010). In a protected area, where human interference is being avoided as much as possible, unnatural sound is generally perceived as an unwanted intrusion. Hence the situation in many parts of SNP (many valleys are open to the road), and especially around the Ofenbergstrasse, does not fit most people's requirements of a recreation area's soundscape (Mace et al. 2004; Miller 2008). While the measured noise can be attributed to both cars and motorcycles, the perceived noise is attributed much more to the latter.

\section{Methods}

A triangulation of methods was applied, combining participant observation (practicing motorcycling, which includes driving through the research area and talking the talk of motorcyclists), quantitative standardized questionnaires (survey) and guided qualitative interviews (see Figure 3). Driving a motorcycle over the Ofenbergstrasse in order to understand better how other motorcyclists perceive this road helped to

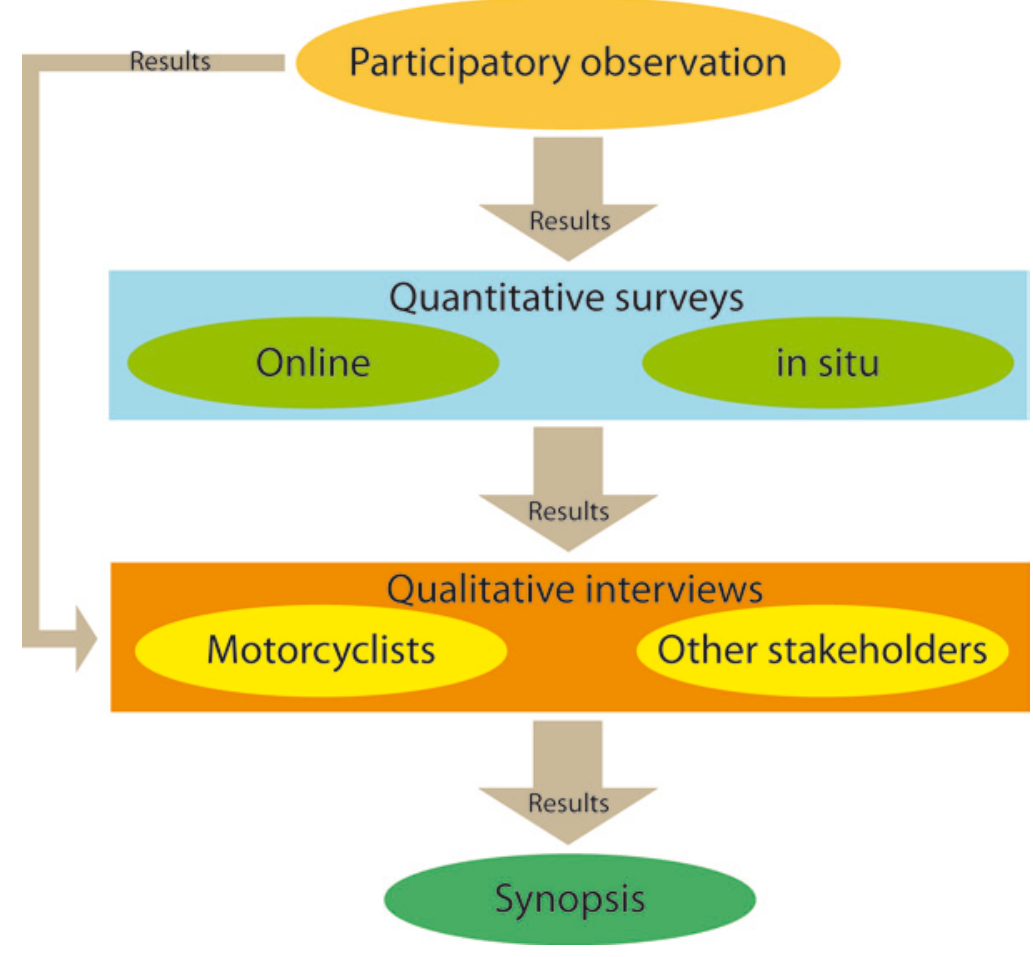

Figure 3 - Research design

get better access to this group, which - often being blamed as noise and / or troublemakers - is somewhat defensive about being interviewed. 134 people completed a questionnaire about their route, their perception of the SNP and the BVM, possible sources of irritation as well as their awareness and willingness to contribute to noise reduction measures. The questionnaire was distributed at the Ofenpass and it was also accessible online (distributed and online questionnaires were analysed separately, however, there was no significant difference between the answers of the samples; $\mathrm{Chi}^{2}$-test). Additionally, qualitative interviews with 19 motorcyclists - as well as with people from the local hospitality industry (that allegedly benefits most from motorcyclists in financial terms), the police (for traffic-related issues, such as speeding or tweaked exhaust mufflers, and because they know the driving behaviour well), hikers (who complain most about noise), and local people (who are ambivalent between disliking the noise and benefiting economically) - were conducted in order to complement the questionnaire data. The interviews were analysed using qualitative coding.

\section{Results}

The typical motorcyclist, so the data from the surveys indicate, driving over the Ofenpass is about 50 years old, male and comes from Germany (34\%), Switzerland (34\%) or Italy $(15.7 \%$; only $8 \%$ from Austria). $20 \%$ are female, of which $75 \%$ are driving their own motorcycle, the rest of the women are pillion riders. The type of motorcycle used most in this terrain is the so-called touring bike, a motorcycle suitable 


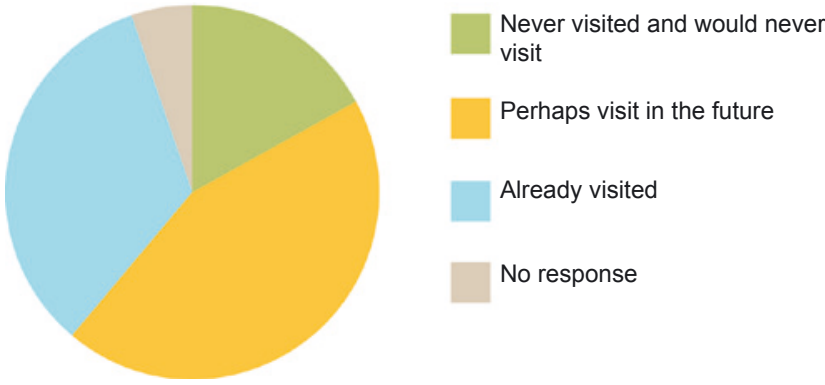

Figure 4 - (Possible) visits by motorcyclists to the SNP $(n=134)$

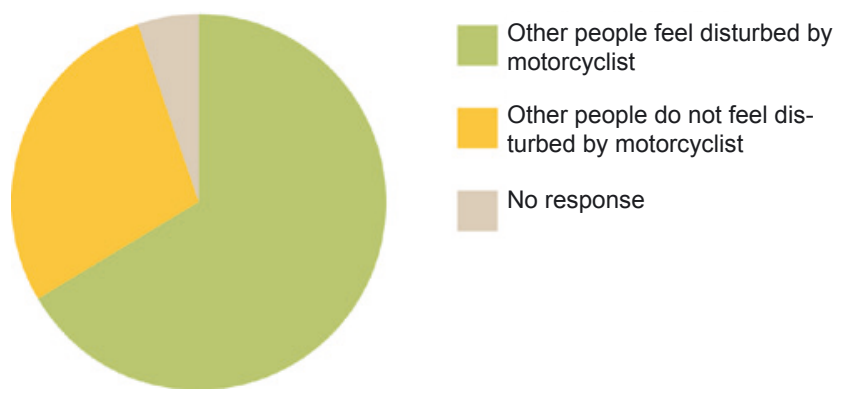

Figure 5 - Motorcyclists' notions of how others perceive disturbances caused by them $(n=134)$

for travelling, with a more or less upright sitting position and with space for luggage. Motorcyclists enjoy the freedom to drive wherever they want, the wind, the scents of nature, being on the road to discover something new and the acceleration of their vehicles. Winding mountain pass roads in beautiful landscapes are most popular (qualitative interviews): „With regard to the nature, it's [Ofenpass] the most beautiful pass in Switzerland" (translated from German by the authors). This quote reveals that for most motorcyclists the quality of a mountain road and its natural surroundings are an important factor for choosing a route. However, they are also aware of the specific natural beauty that is unique to the SNP: "Yes, I am familiar with the national park, but I have never been here [before], I found that fascinating [to drive through the park]." Thus we can conclude that, while the SNP plays a minor role in the decision to drive over the Ofenpass, it is not insignificant.

The motorcyclists cover different spatial and temporal distances, from $200 \mathrm{~km}$ to over $600 \mathrm{~km}$ per day, and time spans from one day to several weeks (survey). Their stops and the exact route are usually chosen spontaneously (qualitative interview). Motorcyclists enjoy the driving physics and usually do not stay long in the same place, but primarily want to be on the road. "Mostly it is because of the driving... and without a predefined destination", says one person (qualitative interview). $58 \%$ of the riders are on the road for more than one day, but there is a significant difference between the nationalities (survey). Swiss, Germans and people from far away countries, such as Great Britain and the Netherlands, are more often on multi-day tours, while Italians and Austrians are just on a day trip when driving over the Ofenpass (survey).
Bikers become aware of the SNP while driving over the Ofenpass, but is not a primary destination for the motorcyclists (interview and survey). Only in rare cases is the SNP approached for hikes by motorcycle (Figure 4). A third of the motorcyclists, esp. the Swiss, have visited the SNP previously (in the sense of deliberately targeting, entering and spending time in the park) and most can imagine visiting the park at some time in the future. Moreover, our data show that the greatest potential for attracting (more) motorcyclists to visit SNP lies with foreigners and young people.

Both the interviewed and the responding motorcyclists of the survey are ambivalent about the extent to which the conservation concept of national parks is at odds with traffic. About $50 \%$ of the respondents agree that there is incompatibility, around 30\% do not (the rest are indifferent). However, in each of the interviews, a personal conflict between passion, individual freedom of movement and the social discourse about nature, or the respondent's own affinity with nature, is apparent: "I think yes, there is a contradiction because in a conservation area means of transport have no business. And no, because I think it's just a road through a vast territory and if we stay on this road and do not veer off ... and do no harm, then that is compatible." Nevertheless, the interviewees mostly argue against the existence of a conflict because traffic is a reality and even in the case of the study area, the economy and tourism of Val Müstair biosphere reserve depends on this road since it is the only access to the rest of Switzerland and the valley's economy largely depends on the lower Engadine area (Buchli et al. 2003). Rather, they say, there must be a possibility for coexistence of nature and traffic.

The interviewed motorcyclists, as well as the respondents of the surveys, are aware that other people may be bothered by their practice, in particular by noise and the manner of driving (Figure 5). Interviewed motorcyclists indicate that they, too, perceive noise and a risky driving behaviour as disturbing factors. However, most motorcyclists suspect that other motorcyclists (rather than they themselves) are causing most noise, speeding or dangerous overtaking. They admit to driving too fast occasionally outside the built-up areas: „Yes, you always drive too fast outside the built-up areas. " However, they claim to observe speed limits within the villages and towns, a result that is confirmed by Züllig (2007). Even though they admit to speeding occasionally, the majority of the motorcyclists describe their manner of driving as appropriate, despite not necessarily complying with the law.

Even though many non-motorcyclists have a negative attitude towards the practice of motorcycling, the people going about this pastime still do spend some money in the region that is welcome and in some cases also needed. Motorcyclists prefer simple accommodation without luxury and appreciate a garage for their motorcycles and a drying room for their clothes (qualitative interview). The data from the surveys reveal that the largest expenditure goes on dinner and the hotel. 
Most spend some money on fuel and snacks. On average, the monetary expenses of the interviewed motorcyclists amount to 45 EUR (55 CHF) per day and person (Figure 6). Persons who are on the road for more than a day (almost 60\% of the respondents) spend more money (58 EUR per day and person) than those on a day trip (25 EUR per day and person). Overall, approximately $70 \%$ of the motorcyclists think that the local population benefits from their spending. Compared to studies of the tourists in the area as a whole, motorcyclists spend less than other tourists. Küpfer (2000) calculated that tourists staying at a hotel spent on average 115 EUR (inflation adjusted to present prices) per day and person. Without accommodation costs they still spent almost 50 EUR on food, transport, souvenirs, etc. Spending less than the average tourist does not mean that motorcyclists are a quantité négligable, for if they are absent their places will not automatically be filled by other (better paying) tourists.

Almost $60 \%$ of the responding motorcyclists show willingness to take voluntary measures when made aware of problems (Figure 7). The interviewed motorcyclists disagree about the usefulness of calls for voluntarily measures (e.g. information signs or provident driving campaigns using posters) to slow down or to drive at lower engine speeds. However, some of the interviewees would even heed such calls. No one suggested to be prepared to buy a (more) silent motorcycle (open question in the questionnnaire), which is a futile point anyway since, according to the Association des Constructeurs Européens de Motocycles (ACEM 2012), there are no really silent motorcycles and the regulations on noise emissions are rather strict in Switzerland. Police measures, such as vehicle (i.e. muffler checks) and speed controls, are supported if these measures are not discriminatory and are enforced for safety reasons and at reasonable spots. Police checks are considered inappropriate especially outside the built-up areas: „(...) single out the goofballs [Krachtïten] but do not denigrate all motorcyclists as criminals. "Most support preventive measures. These may start early during the motorcycle training as well as locally at the Ofenbergstrasse: "Change the thinking, not the law. Do not make the law stricter, you have to influence people and this takes patience. It's much easier to punish someone than to influence [bim / her]."

\section{Discussion}

Motorcyclists regard driving over mountain passes as a highlight since it combines winding roads with breath-taking scenery and fresh mountain air (qualitative interviews). Since the average age of the interviewed motorcyclists is around 50, most motorcyclists passing over the Ofenpass enjoy the landscapes and just being able to ride (interviews). With its easy and well-maintained road, the Ofenbergstrasse provides attractive conditions for both cruising and more ambitious driving. In combination with the steeper Stilfserjochpass, and as a transit to the Dolomites and South

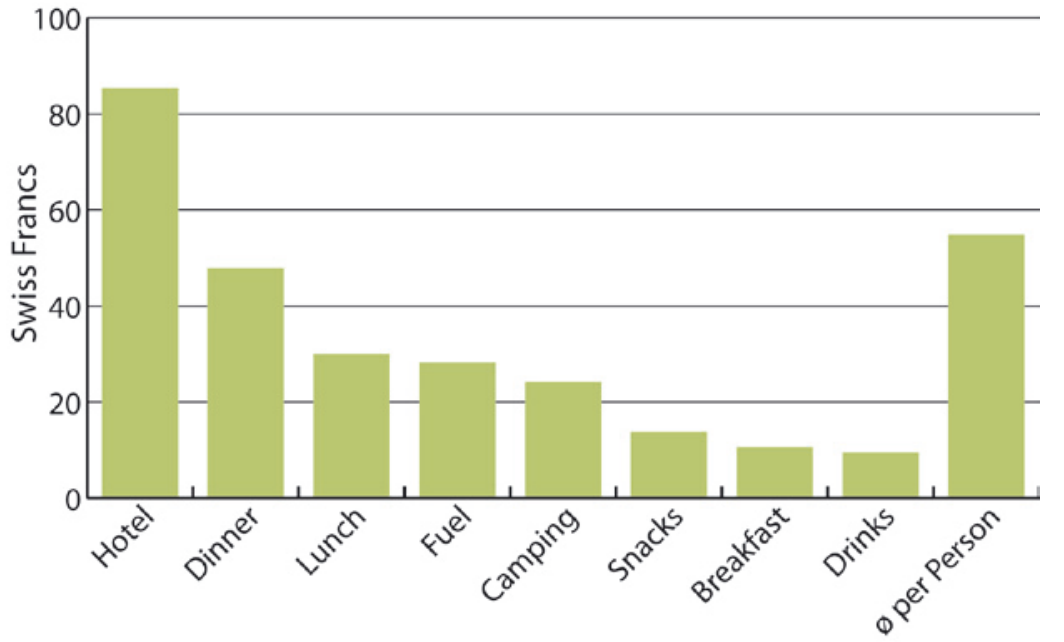

Figure 6 - Average spending on consumer goods in $\operatorname{SFr}(n=86)$

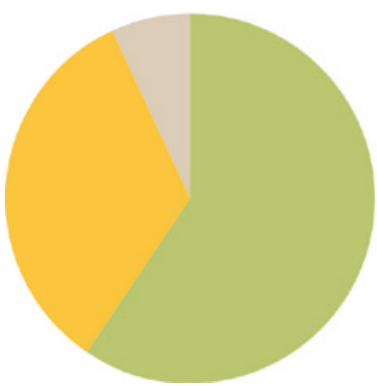

Willingness for voluntary measures

Unprepared to implement noise reduction measures

No response

Figure 7 - Motoryclists' willingness to take noise reduction measures $(n=134)$

Tyrol, it is rated as most appealing. Even though the pass itself and its surrounding landscapes are considered very attractive, the SNP / Ofenpass is not a primary destination; it mostly serves as a transit route to travel to Italy. Although most, esp. Swiss, respondents know the SNP, only 3.3\% say that they specifically came to the region for the SNP (survey). Nevertheless, one third of them have already visited the SNP and mentioned that they would rather visit the SNP using their cars or public transport than using their motorcycles (interview). This suggests that for the practice of motorcycling a beautiful scenery is an argument for a nice trip but the status of a conservation area is not. Also most motorcyclists use the Ofenbergstrasse in transit and just want to be on the road (interviews). So often they make only brief stops and do not rest for a long time in any one place. Therefore their average spending is lower than that of other tourists and since they mostly do not stay in hotels of the region, their overall contribution to the regional gross product is comparatively low. However, there are a few enterprises (i.e. petrol stations, restaurants and hotels) that benefit from this practice (observation). Moreover, since the number of motorcyclists is increasing, their contribution to the regional income is about to rise, too (cf. Rey 2011).

It's not only park visitors and local people who feel annoyed by motorcyclists who drive dangerously, with especially high engine speed or with manipulated mufflers, some motorcyclists also do not like this: "Once 
in a while I have to shake my head about some motorcyclists because I would not drive that way. This troubles me. I have to say this (...), some of them, you have to say, they are simply sick." Reckless behaviour is mostly attributed to young, male drivers but they themselves think that they drive appropriately for their skills and the traffic situation (survey and interview). Moreover, each individual interviewee thinks that the other motorcyclists are the black sheep. On the one hand there is the driving style of the motorcyclists that causes noise and, on the other hand, there is the so-called sound design of a vehicle that is an important factor in the decision to buy a certain make (Stan 2003). For example, a Harley Davidson's deep rumble and a Ducati's thumping sound are characteristics for which these brands are known and bought (it is the quality of the sound rather than its magnitude that is important). The combination of reckless driving by some drivers and engine noise results in a negative image of the practice of motorcycling per se and hence the people driving a motorcycle. Even though many motorcyclists are aware of the noise problem, they do not regard it as so severe as the hikers do. The majority of motorcyclists show an understanding for measures to reduce noise (interviews and survey) and propose the following acceptable actions:

- speed controls inside the built-up areas with a prior warning system (i.e. a sign that says radar control);

- information displays with current speed and sound levels;

- vehicle controls with noise checks and video analyses to raise the awareness of the motorcyclists; and - information about the needs of the SNP and calls for voluntary measures.

Yet, since the Ofenbergstrasse - as a cantonal thoroughfare of national importance - is under cantonal and national (and not municipal) jurisdiction, changes are not easy to implement (Lozza 2009). Hence, proposed speed reduction, warning signs, pedestrian crossings (some of which are currently discussed) or closures would need to be endorsed by the national government (Corti 2000). These legal (and other contexts) have to be taken into account before discussing concrete measures.

While most respondents would have nothing against increased vehicle and speed controls by the police, many add that they would only accept this if it were applied to all motorists and not just to motorcyclists. In order to attenuate potential irritations, they propose to install warning systems announcing traffic speed controls. In the case of the SNP and the BVM, speed and vehicle controls have already been implemented. But outside the built-up area the speed controls are not accepted by the motorcyclists, because in their eyes these controls are not relevant for traffic security (interview). Hence, some respondents are proposing to put more emphasis on prevention in combination with police vehicle controls (interview).
Video analyses and measuring sound levels could provide riders with insights to adjust their driving behaviour in sensitive areas. According to Schulte-Fortkamp (2010) this is not only about noise levels but about the meaning of noise. Therefore discussions about noise reductions should not only be negotiated in terms of noise measured in $\mathrm{dB}(\mathrm{A})$. Rather, this is also about social contexts, behaviour and acceptance. Experiences from the Entlebuch Biosphere Reserve show that campaigns using advertisements at the roadside work quite well, but they have to be repeated regularly to have long lasting effects (personal information by Theo Schnider, Entlebuch BR).

Further, most motorcyclists could imagine changing their driving style voluntarily (survey and interview), but they need more information about the needs of the SNP as well as reminders on the road. The main message of appropriate driving behaviour should be imparted so that car drivers as well as riders could read while driving (for example, with road markings). Most of the motorcyclists do not like it when signs with calls to slow down are imparted in a scaremongering way, a neutral or humorous call is better accepted (interviews). To combine these two measures, a campaign about both the desired manner of driving through the SNP and vehicle controls could be used. People driving incorrectly should be advised with a video analysis about the manner of their driving. A special team, in cooperation with the police, could maintain a dialogue with riders during vehicle controls or at motorcycle meetings.

\section{Conclusion}

People who practice motorcycling are a heterogeneous group of tourists who fulfil their driving passion and lust for travel through their hobby in different ways. The results show both similar opinions as well as controversial issues. Similarities are found on the issue of fascination with motorcycle driving, the demand for non-discrimination in vehicle and speeding controls outside built-up areas. Different views were expressed about the contradiction between traffic and nature conservation and regarding the suitability of measures to reduce noise. There is a concern that the measures might be one-sided at the expense of a certain category of vehicles (e.g. motorcycles) and a desire for the purpose of controls to be made evident and especially that only those persons are fined who drive too noisily or inconsiderately. It's important to ensure that measures are based on discussions with people practicing motorcycling and that they are adapted to local contexts.

As an effective long-term measure, we propose on-site prevention in order to reach motorcyclists during their practice. In addition, the park entrances should be marked more clearly with bigger signs. Our results show that most motorcyclists have an affinity for beautiful scenery, even though they are aware of 
conflicts between recreation-seeking hikers and their hobby. At the same time, practicing motorcyclists do not consider visiting a protected area since the combination of hiking and being on a motorcycle tour does not seem to go well. Moreover, motorcycling basically means being on the road. Hence there is only limited potential to specifically address motorcyclists as visitors. However, people practicing motorcycling are neither exclusively motorcyclists nor does the majority of them live a lifestyle that ultimately revolves around motorcycling. For most this practice is just a (more or less important) hobby. Therefore motorcyclists should not be addressed as an unwanted or troublesome group with little understanding of conservation issues. Regarding them as people whose particular practices are problematic - but who otherwise are like other people - promises better mitigation processes to solve noise-related problems. Since the negative perception of motorcycle noise is not only a result of the actual noise but also of the attitude of the listeners, there is also potential to change these attitudes. However, it is probably more difficult to make tourists seeking recreation in a national park more tolerant to traffic noise when they regard the practice of motorcycling as unnecessary and detrimental to wildlife and recreation. Therefore, while concentrating on noise reduction measures, the aspect of human noise perception should not be disregarded by the management of protected areas. In our study we touched upon several aspects of motorcycling, which we addressed with a broad methodological spectrum in order to grasp how people engaged in this pastime think about driving through a national park. Further research could focus more on the acceptance of concrete and implemented measures for the reduction of noise, and in addition, comparative studies in other protected areas would be interesting.

\section{References}

Association des Constructeurs Européens de Motocycles (ACEM) 2012: Reducing the Traffic Noise Level. Available at: http://www.acem.eu/media/d_ StrivingagainstTrafficNoise_04469.pdf (accessed: 02/02/2012)

Aecherli, W. 2004. Umweltbelastung Lärm. Zürich, Chur.

Bätzing, W. 1998. Verkehr in den Alpen mehr als nur Transitverkehr. Praxis Geographie 48 (2): 33.

Barber, J.R., K.R. Crooks \& K.M. Fristrup 2010. The costs of chronic noise exposure for terrestrial organisms. Trends in ecology \& evolution 25 (3): 180-189.

Birkenfeld, H. 2002. Wider den Verkehrsinfarkt, Der alpine Verkehr auf dem Prüfstand. Geographie heute 23 (203): 26-29.

Buchli, S., B. Buser \& P. Rieder 2003. Die wirtschaftliche Situation im Val Müstair. Zürich: Institut für Agrarwirtschaft, Eidgenössische Technische Hochschule Zürich.

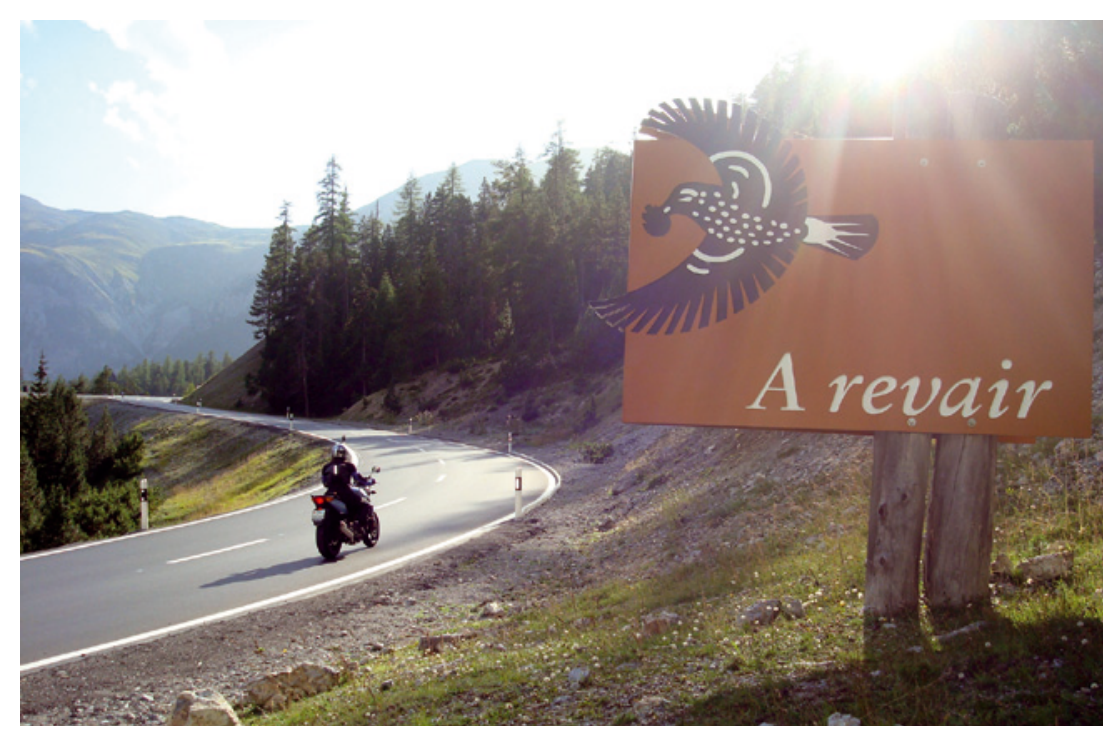

Figure 8-A revair (Goodbye). (C) Andrea Jauss

Bundesamt für Strassen (ASTRA) und Bundesamt für Statistik (BFS) 2011. Schweizerische automatische Strassenverkehrszählung, Fachbereich 11 Mobilität und Verkehr. Available at: http://www.portal-stat. admin.ch/sasvz/files/de/01-GR.xml (accessed: 31/01/2012)

Bundesamt für Statistik (BFS) 2010. 11 Mobilität und Verkehr 2010. Statistik Schweiz: Neuchâtel.

Bundesamt für Umwelt (BAFU) 2011. Belastungsgrenzwerte für Lärm. Available at: http://www.bafu. admin.ch/laerm/10312/10995/index.html?lang=de (accessed: 31/01/2012)

Campell, S., H. Vogler, V. Lafranchi, R. Bollier \& F. Filli 2007. Besucherbefragung Schweizerischer Nationalpark 2007 Schlussbericht. Zernez.

Chan, A.A.Y.-H. \& D.T. Blumstein 2011. Attention, noise, and implications for wildlife conservation and management. Applied Animal Behaviour Science 131 (12): $1-7$.

Corti, T. 2000. Reduktion und Lenkung des touristischen Motorfabrzeugverkehrs - Instrumente und rechtliche Rahmenbedingungen. Eidgenössische Technische Hochschule (ETH). Zürich.

Geser, R. 1995. Die schönsten Alpenpässe mit dem Motorrad. Ludwig Freizeitführer. München.

Heutschi, K. 2010. Untersuchungsbericht Nr. 455'585, int. 511.2471 mit dem Auftrag: Ermittlung der durch Motorräder verursachten akustischen Immissionen im Nationalpark. EMPA Abteilung Akustik und Lärmminderung. Dübendorf.

Jauss, A. 2012. Motorradreisende am Ofenpass: Wahrnehmung des Ofenpasses und des Schweizerischen Nationalparks aus der Sicht der Motorradreisenden. Masterarbeit, Geographisches Institut, Universität Zürich, Zürich.

Kohler, T. 2005. Motorradfahren in der Schweiz. 18951930. Band 1. Verein Freunde alter Motorräder Schweiz (Hrsg.). Schaffhausen.

Kohler, T. 2007. Motorradfahren in der Schweiz 1930 1959. Band 2. Verein Freunde alter Motorräder Schweiz (Hrsg.). Schaffhausen. 
Kraftfahrt-Bundesamt Deutschland 2013. KBA Fahrzengklassen und Aufbauarten: Zeitreibe von 1955 bis 2013. Fahrzeugstatistik. KBA. Retrieved March 13, 2013, from http://www.kba.de/cln_032/ nn_191172/DE/Statistik/Fahrzeuge/Bestand/ FahrzeugklassenAufbauarten/b_fzkl__zeitreihe. html (accessed: 14/03/2013)

Küpfer, I. 2000. Die regionalwirtschaftliche Bedeutung des Nationalparktourismus: Untersucht am Beispiel des Schweizerischen Nationalparks. Zernez: Nationalparkforschung Schweiz.

Lozza, H. 2009. Nutzungsdruck im Schweizerischen Nationalpark. Collage, Zeitschrift für Planung, Umwelt und Städtebau 2: 15-18.

Mace, B.L., P.A. Bell \& R.J. Loomis 2004. Visibility and Natural Quiet in National Parks and Wilderness Areas: Psychological Considerations. In: Environment and Behavior 36 (5): 5-31.

Meier, M. 2010. Die Einstellung der Lokalbevölkerung zum Schweizerischen Nationalpark. Geographisches Institut, Universität Zürich. Zürich.

Miller, N.P. 2008. US National Parks and management of park soundscapes: A review. Applied Acoustics 69 (2): 77-92.

Omlin, S. \& M. Brink 2010. Lärmstudie Nationalpark, ErgebnissederBesucherbefragung August2010.D-MTECPublic Organizational Health Eidgenössische Technische Hochschule (ETH). Zürich.

Rey, V. 2011. Motorradtourismus in den Schweizer Alpen. Höhere Fachschule für Tourismus (HFT). Luzern.

Schatzki, T.R. 2002). The site of the social: a philosophical account of the constitution of social life and change. University Park: Pennsylvania State University Press.

Schulte-Fortkamp, B. 2010. Motorradlärm. Vortrag am 26.04.2010, Verbraucherforum Motorradlärm, Berlin. Available at: http://www.umweltbundesamt. de/laermprobleme/veranstaltungen/motorradlaerm/ schulte-fortkamp.pdf (accessed: 02/02/2012)

Znoj, H. 2011. Die Psychologie des Motorrads, Zur Wechselwirk.ung von Mensch und Maschine. 1. Auflage. Bern.

Züllig, C. 2007. Verkehr in der Biosfera Val MüstairParc Naziunal - Analyse und Handlungsempfehlungen. Hochschule für Wirtschaft (HSW). Luzern.

\section{Authors}

\section{Andrea Jauss}

studied Geography and Agricultural Economy at the University of Zurich and at ETH. She completed her Master in Human and Economic Geography and graduated 2012. Currently she is finishing her training as a high-school teacher. She is an enthusiastic motorcyclist. Grindelstrasse 7, 8604 Volketswil, Switzerland. Email: andrea.jauss@bluewin.ch

Norman Backhaus

(corresponding author), teaches Human Geography at the University of Zurich. In his research he focuses on conservation, spatial appropriation and globalization in Switzerland and Southeast Asia. He is president of the Swiss National Park's research commission. Department of Geography, University of Zurich, Winterthurerstrasse 190, 8057 Zurich, Switzerland. Email: norman.backhaus@geo.uzh.ch 